\title{
Średniowieczny katalog biskupów poznańskich w Roczniku lubińskim ukryty
}

\begin{abstract}
Zarys treści: Autor artykułu rozwija stawianą już wcześniej ostrożnie hipotezę o istnieniu katalogu biskupów, prowadzonego przy katedrze w Poznaniu zapewne od odnowienia biskupstwa ok. 1075 r. aż do początków XIV w. Jego ślad stanowią zapiski o biskupach dopisane w połowie XIII w. do Rocznika powstałego w benedyktyńskim opactwie w Lubiniu.

Abstract: The author of the article expands a previous carefully formulated hypothesis about the existence of a catalogue of bishops kept at the cathedral in Poznan probably from the revival of the bishopric in about 1075 all the way to the beginning of the fourteenth century. Its trace consists of records about the bishops added in the mid-thirteenth century to a Rocznik written in the Benedictine abbey in Lubin.
\end{abstract}

Słowa kluczowe: średniowiecze, Kościół, katalogi biskupie, biskupstwo poznańskie, klasztor w Lubiniu Keywords: Medieval Church, bishop catalogs, bishopric of Poznań, monastery in Lubiń

Wczesne dzieje biskupstwa poznańskiego są słabo rozpoznane. Uwagę historyków przykuwały przede wszystkim czasy najdawniejsze, epoka biskupów Jordana (968-984) i Ungera (zm. 1012), pełne wielkich zagadek, jak okoliczności fundacji i charakter pierwszego biskupstwa czy kwestia jego podległości metropolii magdeburskiej ${ }^{1}$. Ciemne pozostają jednak także następne dwa wieki. Aż do początków XIII w., gdy wraz z narastającym wtedy szybko zasobem dokumentów wkraczamy wreszcie na nieco pewniejszy grunt, wysoce sporne pozostaje samo ustalenie pocztu kolejnych ordynariuszy. Poznań nie ma właściwego średniowiecznego katalogu swych biskupów i wyróżnia się pod tym względem wśród polskich diecezji, których wiele takimi zestawieniami dysponuje (Kraków, Wrocław, Włocławek) ${ }^{2}$. Katalog biskupów poznańskich ułożył dopiero Jan Długosz ${ }^{3}$. W odniesieniu do

\footnotetext{
${ }_{1}$ Podsumowanie dyskusji dał ostatnio D. A. Sikorski, Kościót w Polsce za Mieszka I i Bolesława Chrobrego. Rozważania nad granicami poznania historycznego, Poznań 2001, rozdz. 4-5.

${ }^{2}$ Katalogi biskupów krakowskich, wyd. J. Szymański, MPH s.n., t. 10, Warszawa 1974; Catalogi episcoporum Vladislaviensium, wyd. W. Kętrzyński, w: MPH, t. 4, Lwów 1884, s. 16-30 (zob. A. Bogucki, Przynależność administracyjna Kujaw w XI i XII wieku, w: Włocławek i jego dzieje na tle przemian Kujaw i ziemi dobrzyńskiej, Włocławek 1995, s. 16-17); Katalogi biskupów wrocławskich, wyd. W. Kętrzyński, w: MPH, t. 6, Kraków 1893, s. 534-584; A. Birkenmajer, Nowy katalog biskupów wrocławskich, w: Studia historyczne ku czci Stanisława Kutrzeby, t. 2, Kraków 1938, s. 29-38; zob. O. Schmidt, Untersuchungen zu den Breslauer Bischofskatalogen, Darstellungen und Quellen zur schlesischen Geschichte, t. 25, Breslau 1917; T. Jurek, Zagadka biskupa wrocławskiego Roberta, Sobótka, 45, 1990, s. 1-11.

${ }_{3}$ Catalogus episcoporum Posnaniensium, w: Joannis Dlugossii Opera omnia, t. I, wyd. I. Polkowski, Ż. Pauli, Kraków 1887, s. 479-513; tłumaczenie polskie: Katalogi biskupów poznańskich, oprac. J. Wiesiołowski, Poznań 2004. Skrócone dane z zakończonego w 1475 r. katalogu Długosz wnosił też następnie do swych, ukończonych już w zasadniczym zrębie, Roczników; czynił to jednak niezbyt starannie, a szukając wolnych miejsc w rękopisie, nie zawsze dbał o zgodność dat
} 
czasów najstarszych nie dysponował jednak żadnymi dodatkowymi, nam dziś nie znanymi, źródłami, a swą niewiedzę pokrywał — jak miał to w zwyczaju — zmyśleniami. Długoszowe informacje o biskupach z XI-XII w. nie mają więc żadnej samodzielnej wartości ${ }^{4}$. W celu zrekonstruowania szeregu biskupów oprzeć się trzeba na źródłach im współczesnych.

Szczególną uwagę zwraca ciąg imion dwunastowiecznych biskupów poznańskich zawarty w Roczniku lubińskim. Pięciokrotnie już publikowany Rocznik ${ }^{5}$ jest od dawna znany badaczom, jego zapiski były oczywiście pilnie wykorzystywane, ale nie zwracano dotąd należytej uwagi na pewne aspekty, uchwytne zresztą już dzięki uwagom w pierwszej edycji sprzed półtora wieku, a istotne dla krytyki źródłoznawczej. Zabytek ten zachowany jest niestety w stanie szczątkowym. $\mathrm{Z}$ pierwotnie większej całości zachowała się tylko jedna pergaminowa karta oraz fragment drugiej karty, wyjęte z wyklejek jednego ze starodruków z dawnej biblioteki klasztoru benedyktyńskiego w Lubiniu, przeniesionych po jego kasacie do Biblioteki Królewskiej w Berlinie (obecnie Staatsbibliothek zu Berlin, sygn. Ms. Lat. Fol. 321). Przechowanie rękopisu w lubińskiej księdze oraz treść samych wpisów, mówiących o opatach, nie pozwalają wątpić w związek rocznika z opactwem lubińskim. Wśród kilkunastu zapisów rocznikarskich z pierwszej karty znajduje się kilka dotyczących biskupów ${ }^{6}$ :

\section{Bogufalus episcopus Poznaniensis obiit, Peanus succedit. \\ MCLII Peanus episcopus Poznaniensis obiit, Stephanus succedit. \\ MCLIX Stephanus episcopus Poznaniensis obiit, Bernardus succedit. \\ MCLXIIII Bernardus episcopus Poznaniensis obiit, Cherubinus succedit. \\ MCLXXII Cherubinus episcopus Poznaniensis obiit, Raduanus succedit.}

Ich umieszczenie w klasztornym roczniku nie może dziwić. Chodzi wszak o lokalnych ordynariuszy, którymi mnisi musieli się interesować, tym bardziej, że rocznik notował także zmiany na innych stolicach biskupich (Wrocław, Kraków). Wyliczone wpisy dotyczące biskupów poznańskich wyróżniają się jednak zdecydowanie na tle reszty Rocznika. Wszystkie zostały dopisane już po przygotowaniu zasadniczego trzonu tekstu i wszystkich uzupełnień dokonała jedna ręka, inna niż ta, którą spisany został trzon tekstu. Widać to szczególnie wyraźnie w zapisce z 1172 r., gdzie informacja o śmierci Cherubina i ordynacji Radowana umieszczona jest po wniesionej główną ręką prowadzącą rocznik wiadomości o wyborze opata Kolumby.

Wyjaśnienia wymaga datowanie tych uzupełnień. Dotychczasowi wydawcy uważali, że obydwie znane karty spisane są zasadniczo jedną ręką z drugiej połowy XIII w., a ostatnia $\mathrm{z}$ dat wymienionych na drugiej z tych kart (rok 1275) wyznacza orientacyjny czas opracowania całego Rocznika. Ręka uzupełniająca informacje o biskupach wydawała się bądź współczesna warstwie głównej (A. Bielowski), bądź jednak późniejsza (W. Kętrzyński wskazywał na XIV w., co zaakceptowała B. Kürbis). Podkreślano też, że ręka ta wniosła również jedno uzupełnienie (o translacji św. Jadwigi z 1268 r.)

(Ioannis Dlugossi Annales seu cronicae incliti Regni Poloniae, lib. I-II, Warszawa 1964, s. 180, 239, 284, 305, 313; lib. III-IV, Warszawa 1970, s. 59, 93, 158, 223, 308; lib. V-VI, Warszawa 1973, s. 42, 48, 49, 57, 73, 103, 107, 114, 140, 166, 210).

${ }^{4}$ S. Karwowski, Najstarsi Długoszowi biskupi poznańscy wobec krytyki, ,Roczniki Towarzystwo Przyjaciół Nauk Poznańskiego", 35, 1909, s. 336; szerzej zob. E. Potkowski, Fiktive Biographien in den Katalogen polnischer Bischöfe von Jan Dlugosz, w: Fälschungen im Mittelalter, Hannover 1988, t. I, s. 395-416; tenże, Fikcja i historia u Długosza, „Przegląd Humanistyczny", 31, 1987, s. 47-63.

5 Annales Lubinenses, wyd. R. Röpell, W. Arndt, w: MGH SS, t. 19, Hannoverae 1866, s. 578-580; Annales Poloniae, wyd. G. H. Pertz, Scriptores rerum Germanicarum, Hannoverae 1866, s. 3-5; Rocznik lubiński, wyd. A. Bielowski, w: MPH, t. 2, Lwów 1872, s. 774-776 (na tabl. VII, po s. 942, litografia z próbką pisma); Annales Lubinenses, wyd. W. Kętrzyński, w: MPH, t. 5, Lwów 1888, s. 861-873; Roczniki wielkopolskie, wyd. B. Kürbis, MPH s.n., t. 6, Warszawa 1962, s. XXXVIIXLV, 111-122 (tu fotokopie obu kart rękopisu); ponieważ trzy pierwsze wydania obejmowały tylko jedną kartę z zapiskami z XII w., fragmenty trzynastowieczne wydano osobno: Annalium Lubinensium continuatio, wyd. M. Perlbach, w: MGH SS, t. 29, Hannoverae 1892, s. 422-423.

${ }^{6}$ Wszystkie cytaty odwołują się do wydania B. Kürbis. 
na karcie drugiej’. Opinie te wygłaszane były jednak bez bliższej argumentacji. Zauważono już, że zachowane karty Rocznika różnią się rozplanowaniem danych chronologicznych, a także pismem, które na karcie pierwszej (kompletnej) wydaje się starsze i przypomina to z lubińskiej Księgi brackiej z przełomu XII i XIII w. Starszą partię Rocznika datować więc należy na początek XIII w., a dopiero jego kontynuację — na schyłek tego stulecia ${ }^{8}$. Sprostować też trzeba, że ręka uzupełnień o biskupach nie jest na pewno tożsama z tą, która uczyniła dopisek pod $1268 \mathrm{r}$. Widać natomiast, że pismo tych dodatków jest zasadniczo podobne do pisma podstawowej ręki karty pierwszej, a ta — jak wskazywaliśmy — okazuje się dużo starsza, niż niegdyś sądzono. Nasz pisarz uzupełniający wywodził się niewątpliwie z tej samej szkoły klasztornej. Wydaje się, że ten sam dukt rozpoznać można także w dokumentach spisywanych w lubińskim skryptorium w połowie XIII w., choć dokładna identyfikacja wymagałaby bardzo szczegółowych analiz, na które nie ma tu miejsca9. Uzupełnienia wnoszono zatem najpewniej około $1250 \mathrm{r}$.

Począwszy od dziewiętnastowiecznych wydawców, doceniano wielkie znaczenie zapisek dla ustalenia chronologii biskupów poznańskich, zwłaszcza w kontekście krytyki przekazu Długosza ${ }^{10}$. Nie podjęto natomiast krytycznej refleksji na temat pochodzenia tych zapisów. Jednolity tematycznie i treściowo, wniesiony jednorazowo przez jednego pisarza zbiór dopisków w tekście Rocznika lubińskiego musiał niewątpliwie pochodzić z jednego źródła. Brygida Kürbis ostrożnie sugerowała, że wykorzystano tu jakieś „,notatki katedralne”, „może katalog lub rocznik”11. Wydaje się, że w swym wnioskowaniu okazała przesadną ostrożność. Ze względu na fakt, że dopisywane informacje dotyczyły (na przestrzeni kilkudziesięciu lat) wyłącznie sukcesji ordynariuszy poznańskich, a objęły wszystkich wówczas urzędujących, źródłem, z którego zostały zaczerpnięte, musiał być bez wątpienia katalog biskupów ${ }^{12}$. Istniał zatem taki wykaz już w połowie XIII w. Skoro nie znał go pierwszy redaktor Rocznika lubińskiego, a stosowne informacje dopisał dopiero później któryś z jego konfratrów, katalog ten najpewniej nie był prowadzony w samym Lubiniu — gdzie rocznikarz, niewątpliwie zainteresowany pamiątkami przeszłości, powinien go znać. Naturalnym miejscem dla prowadzenia katalogu była oczywiście katedra poznańska. Stąd odpisy rozchodzić się mogły po całej diecezji i tu przekaz ten poznał także któryś z lubińskich mnichów. We Wrocławiu, jak wskazują najstarsze kopie, katalog biskupów nosił tytuł Chorus Wratislaviensis, co wyraźnie wskazuje na związek z katedrą czy to poprzez wpisanie do jakiejś księgi chórowej, czy też poprzez umieszczenie (na tablicy?) w chórze katedralnym ${ }^{13}$. Podobnie mogło być i w Poznaniu.

Skromny zestaw pięciu notat annalistycznych pozwala jednak zastanowić się nad kwestią rekonstrukcji kształtu pierwotnych zapisów katalogowych. Niewątpliwie, tak jak w przypadku najstar-

\footnotetext{
${ }^{7}$ Rocznik lubiński [Bielowski], s. 774; Annales Lubinenses [Kętrzyński], s. 863; Roczniki wielkopolskie, s. XXXIX.

8 Z. Perzanowski, Opactwo benedyktyńskie w Lubiniu. Studia nad fundacja i rozwojem uposażenia w średniowieczu, Wrocław 1978, s. 16-17; także G. Labuda, Główne linie rozwoju rocznikarstwa polskiego w wiekach średnich, Kwart. Hist., 78, 1971, s. 832, datował powstanie Rocznika lubińskiego na ok. 1190 r., zapiski trzynastowieczne uważając za późniejszą kontynuację.

${ }_{9}$ Pismo skryptorium lubińskiego analizują M. Bielińska, Kancelarie i dokumenty wielkopolskie XIII wieku, Wrocław 1967, s. 115, 223-228, oraz F. Sikora, Dokumenty i kancelaria Przemysła I oraz Bolestawa Pobożnego 1239-1279 na tle wspótczesnej dyplomatyki wielkopolskiej, Wrocław 1969, s. 69-73, 78-81, którzy dochodzą jednak do sprzecznych wniosków w sprawie identyfikacji poszczególnych rąk; w pracach tych zamieszczone są też próbki pisma (M. Bielińska, fig. 3; F. Sikora, tabl. 3, 6a-6c).

${ }^{10}$ Annales Lubinenses [Röpell], s. 579; Annales Poloniae, s. 4; Annales Lubinenses [Kętrzyński], s. 866-867. Zob. też przyp. 18. Odosobnione stanowisko zajmował J. Nowacki, Dzieje archidiecezji poznańskiej, t. 1-2, Poznań 1959-1964, tu t. 2, s. 47-48, który wskazywał, że Rocznik też „nie jest wolny od sprzeczności i błędów” i dawał pierwszeństwo Długoszowi.

${ }^{11}$ Roczniki wielkopolskie, s. XLI.

${ }^{12} \mathrm{O}$ gatunku tym zob. J. Szymański, Z zagadnień średniowiecznej biografistyki. Katalogi dostojnicze. Studium źródłoznawcze, Warszawa 1969.

${ }^{13}$ Katalogi biskupów wrocławskich, s. 562 (katalog lubiąski: hic videtur falli chorus Wratislaviensis); zob. O. Schmidt, Untersuchungen, s. 43, 137.
} 
szych zabytków tego typu z innych diecezji polskich, chodziło o zwykłe zestawienie ciągu kolejnych imion rządców diecezji (a więc tzw. katalog prosty, w przeciwieństwie do późniejszej maniery podawania szerszych informacji biograficznych $)^{14}$. Jednostajny układ zapisek w Roczniku (X. obiit, $Y$. succedit) nie był na pewno zaczerpnięty z katalogowej podstawy. Był to bowiem schemat wypracowany już przez głównego redaktora Rocznika. W taki właśnie sposób notował on następstwo innych biskupów (pod 1145, 1252, 1253, 1258, 1264), opatów (pod 1254), a także książąt (pod 1247). $\mathrm{W}$ ten sam model zapisu, powtarzający się regularnie w Roczniku, wpisał się także mnich wnoszący uzupełnienia. W pierwotnym katalogu taka konstrukcja byłaby nieoszczędna, wymagałaby bowiem powtarzania każdego występującego biskupa dwukrotnie (raz przy ordynacji, raz przy zgonie). Podstawowe pytanie brzmi, czy katalog zawierał też daty (ordynacji i/lub śmierci). Genetycznie najwcześniejszy jest typ katalogu bez elementów chronologicznych ${ }^{15}$. W Polsce najstarsze znane obecnie redakcje katalogów krakowskich (z ok. 1266/1267 r.) i włocławskich (z ok. 1400 r.) żadnych dat nie zawierają ${ }^{16}$. Katalogi wrocławskie już od najstarszej redakcji (z ok. 1270 r.) operują datami (wiarogodnymi) i tak musiał wyglądać ich pierwowzór ${ }^{17}$. Rozstrzygnięcie tej kwestii w odniesieniu do rekonstruowanego katalogu poznańskiego wymaga szczegółowej weryfikacji danych zawartych w zapisach Rocznika lubińskiego ${ }^{18}$. Jeżeli daty okażą się wiarogodne, oznaczać to będzie, że musiały być zaczerpnięte z katalogowej podstawy, nie do pomyślenia jest bowiem, by po stu kilkudziesięciu latach udało się je poprawnie uzupełnić.

Biskup Boguchwał (według Rocznika zm. 1146) występuje w notycji dotyczącej nadania Lusowa przez Mieszka Starego post victoriam que fuit in Poznan. Chodzi o zwycięską bitwę z oblegającymi gród poznański wojskami seniora Władysława II wiosną 1146 r., a nadanie miało miejsce najpewniej zaraz po tym zdarzeniu ${ }^{19}$. Biskup miał umocnić nadanie zapowiedzią klątwy na jego gwałcicieli. W tekście notycji, który nie mógł raczej powstać w zbyt znacznym oddaleniu czasowym od tych wypadków, Boguchwał jest określony jako zmarły (bone momorie). Umarł więc najpewniej niebawem po odebraniu lusowskiego nadania. Ustalenie to odpowiada dokładnie informacji Rocznika.

Biskup Pean (według Rocznika rządzący w 1. 1146-1152) identyczny jest niewątpliwie z kanclerzem książęcym świadczącym w dokumencie legata Humbalda, opatrzonym datą 1146 r. ${ }^{20}$ Sprawa datowania tego dyplomu jest jednak bardzo problematyczna. Dokument został wystawiony w Rzymie (najpewniej wiosną 1147 r.), a legat poświadczył nim dokonane przez siebie podczas pobytu w Gnieźnie (zapewne w 1145 r.?) zatwierdzenie nadania polskich książąt dla klasztoru w Trzemesznie, które miały miejsce najpewniej podczas pogrzebu ich matki, księżnej Salomei (zm. 27 VII 1144). Lista świadków, w której występuje interesujący nas kanclerz, odnosi się na pewno do tej ostatniej czynności, czyli nadania książęcego. Pean zostać mógłby zatem biskupem najwcześniej w sierpniu 1144 r. W nekrologu opactwa lubińskiego zapisany został pod datą 1 października (przy

\footnotetext{
${ }_{14}$ Typologizację katalogów przeprowadza J. Szymański, Z zagadnień, s. 13-25, przy czym wyróżnione przezeń typy I (lista imion) i II (lista z datami) odpowiadają temu, co O. Schmidt, Untersuchungen, określał jako „einfache Kataloge”, przeciwstawiane późniejszym redakcjom, podającym bardziej rozbudowane noty o poszczególnych biskupach.

15 J. Szymański, Z zagadnień, s. 14-17.

${ }^{16}$ Katalogi biskupów krakowskich, s. 24-25; Catalogi episcoporum Vladislaviensium, s. 24. Daty ma kolejna redakcja katalogu krakowskiego, opracowana przez uczonego Jana Dąbrówkę (Katalogi biskupów krakowskich, s. 30 n.).

17 Zob. niżej, przyp. 34.

${ }^{18}$ Sprawa ustalenia pocztu biskupów poznańskich w XII w. ma obszerną literaturę: S. Karwowski, Biskupi poznańscy z XII i początku XIII wieku, „Roczniki Towarzystwa Przyjaciół Nauk Poznańskiego”, 37, 1911, s. 111-146; G. Sappok, Die Anfänge des Bistums Posen und die Reihe seiner Bischöfe von 968-1498, Leipzig 1937, s. 84 n.; J. Nowacki, Dzieje, t. 2, s. 47 n.; J. Maciejewski, Episkopat polski doby dzielnicowej 1180-1320, Kraków-Bydgoszcz 2003, s. 252 n.; J. Dobosz, Monarchia i możni wobec Kościoła w Polsce do początku XIII wieku, Poznań 2002, s. 316-321.

${ }_{19}$ KDWlkp., t. 1, [wyd. I. Zakrzewski], Poznań 1877, nr 8; Repertorium polskich dokumentów doby piastowskiej, oprac. Z. Kozłowska-Budkowa, Kraków 1937 (wyd. 2: Kraków 2006), nr 45.

${ }^{20}$ KDWlkp., t. 1, nr 12; Repertorium, nr 44; nowe wydanie: T. Jurek, Pierwsze wieki historii Łęczycy, w: Początki Łęczycy, red. R. Grygiel, T. Jurek, t. 3, Łódź 2014, s. 124, gdzie też (s. 54-55) podsumowanie dyskusji nad datacją.
} 
czym nowożytną ręką dodano też datę roczną: 1151, ale jest ona zaczerpnięta z Długosza i w związku z tym pozbawiona samodzielnej wartości) ${ }^{21}$, zaś w nekrologu opactwa na wrocławskim Ołbinie - pod 16 kwietnia $^{22}$.

Biskup Stefan (według Rocznika rządzący w 1. 1152-1159) występuje jako świadek dokumentu fundacyjnego klasztoru cystersów w Łeknie ${ }^{23}$. Dyplom datowany jest na 1153 r., ale uważa się, że zgodnie z cysterskimi zwyczajami zastosowano tu styl Zwiastowania w odmianie pizańskiej, a więc chodziłoby o okres od 25 III 1152 do 24 III 1153 r. Odpowiada to przedziałowi wskazanemu w Roczniku lubińskim. Śmierć jakiegoś biskupa Stefana notuje Rocznik kapituły krakowskiej już pod 1156 r. $^{24}$, ale nie wiadomo, czy chodzi tu o naszego biskupa poznańskiego. W grę wchodzi również Stefan poświadczony w Lubuszu w 1149 r. ${ }^{25}$ Nie wiadomo też, do którego z nich odnieść wpis w nekrologu lubińskim pod dniem 2 marca $^{26}$.

Biskup Bernard (według Rocznika rządzący w 1. 1159-1164) nie jest skądinąd znany. Niemal wszystkich członków polskiego episkopatu wymienia wprawdzie datacja dokumentu wystawionego podczas uroczystej konsekracji kolegiaty w Łęczycy w dniu 21 IV 1161 r., ale biskup poznański tam się nie pojawia. Najprawdopodobniej znajdował się wówczas w poselstwie do Italii, na synod zwołany przez cesarza Fryderyka Barbarossę do Lodi ${ }^{27}$.

Cherubin (według Rocznika rządzący w 1. 1164-1172) i Radowan ${ }^{28}$ (według Rocznika od 1172 r.) winni być rozpatrywani razem. Obaj znani są jako kanclerze księcia Mieszka Starego: Radowan był nim w 1152/1153 r. (świadczy we wspomnianym już dokumencie łekneńskim) ${ }^{29}$, zaś Cherubin w 1166/1167 r. (świadczy w dokumencie dla cystersów z Jędrzejowa) ${ }^{30}$. Cherubin już jako biskup wymieniony jest przez Wincentego Kadłubka wśród członków episkopatu zebranych w 1180 r. na zjeździe, na którym uchylono zasady senioratu, a Kazimierz Sprawiedliwy ogłosił pierwsze przywileje immunitetowe dla Kościoła ${ }^{31}$. Wiarogodność tej informacji, pochodzącej od naocznego świadka, nie może ulegać wątpliwości. Z kolei Radowan, jako biskup poznański wspomniany jest przez Długosza w relacji o fundacji szpitala Św. Michała pod Poznaniem, opatrzonej dokładną datą 6 V $1170 \mathrm{r}$. Wprawdzie relacja ta zredagowana jest zasadniczo na podstawie dokumentu dla joannitów (którzy przejęli potem szpital) z 1218 r., ale wydaje się prawdopodobne, że piętnastowieczny dziejopis widzieć mógł jakąś datowaną na 1170 r. zapiskę wymieniającą imiennie biskupa i datę dzienną̧ ${ }^{32}$. Data nie wygląda w każdym razie na zmyślenie. Gdyby Długosz miał ją bowiem zmyślić, to zmyśliłby z pewnością tak, aby pasowała do przyjętych przez niego dat rządów pontyfikatu Radowana (1156-1162). Z przytoczonych faktów wynika w każdym razie, że Radowan musiał być biskupem przed Cherubi-

\footnotetext{
${ }^{21}$ Księga bracka i nekrolog opactwa Panny Marii w Lubiniu, wyd. Z. Perzanowski, MPH s.n., t. 9/2, Warszawa 1976, s. 100; dopisek odnotowuje edycja W. Kętrzyńskiego, Annales Lubinenses [Kętrzyński], s. 642.

${ }^{22}$ Nekrolog opactwa Św. Wincentego we Wrocławiu, wyd. K. Maleczyński, MPH s.n., t. 9/1, Warszawa 1971, s. 37.

${ }^{23}$ KDWlkp., t. 1, nr 18; Repertorium, nr 53; ostatnio J. Dobosz, Dokument fundacyjny klasztoru cystersów w Łeknie, w: Studia i materiały do dziejów Pałuk, t. 1, Poznań 1989, s. 53-83.

${ }^{24}$ Najdawniejsze roczniki krakowskie i kalendarz, wyd. Z. Kozłowska-Budkowa, MPH s.n., t. 5, Warszawa 1978, s. 60.

${ }_{25}$ Schl. UB, t. 1, wyd. H. Appelt, Wien-Köln-Graz 1963-1971, nr 19; w nekrologu ołbińskim zapisany pod 4 kwietnia (Nekrolog opactwa, s. 34); F. Funcke, Regesten der Bischöfe von Lebus bis zum Jahre 1418, „Brandenburgia. Monatsblatt der Gesellschaft für Heimatkunde der Provinz Brandenburg”, 24, 1916, s. 195 nr 5, przyjął, że biskup zmarł w 1158 r., ale jego wyliczenia są bezpodstawne.

${ }^{26}$ Księga bracka, s. 36 (w komentarzu zestawienie dyskusji).

${ }^{27}$ CDMas., wyd. J. K. Kochanowski, t. 1, Warszawa 1919, nr 87; Repertorium, nr 61; zob. T. Jurek, Pierwsze wieki, s. 59-60.

${ }^{28}$ Używam tej formy, na którą wskazują zapisy źródłowe, choć w literaturze przyjęło się pisać Radwan (zob. A. Gąsiorowski, w: PSB, t. 30, Wrocław 1988, s. 1).

29 Zob. przyp. 23.

${ }^{30}$ W. Semkowicz, Nieznane nadania na rzecz opactwa jędrzejowskiego z XII wieku, Kwart. Hist., 24, 1910, s. 69-70, 83-85.

${ }^{31}$ Mistrza Wincentego zwanego Kadtubkiem Kronika polska, wyd. M. Plezia, MPH s.n., t. 11, Kraków 1994, s. 149 (IV 9,4); zob. T. Jurek, Pierwsze wieki, s. 76-77.

32 Ioannis Dlugossii Annales, lib. V-VI, s. 94; zob. A. Gąsiorowski, Najstarsze dokumenty poznańskiego domu joannitów, cz. 1, St. Źródł., 8, 1963, s. 94-95; T. Ginter, Działalność fundacyjna księcia Mieszka III Starego, Kraków 2008 , s. 76.
} 
nem - tak przyjmuje się powszechnie w literaturze ${ }^{33}$. Rozbieżność tej konstatacji z zapisem Rocznika lubińskiego łatwo wyjaśnić błędem pisarza, który po prostu pomylił kolejność biskupów. Taka mechaniczna omyłka zrozumiała jest zwłaszcza przy przepisywaniu tekstu w formie listy, jaką musiał mieć właśnie postulowany przez nas katalog.

Wynik weryfikacji jest więc zasadniczo pozytywny. Uwzględniając przestawienie dwóch ostatnich osób oraz pamiętając o wątpliwościach wokół Stefana (w którego przypadku data śmierci może również być przepisana $\mathrm{z}$ błędem), w niemal wszystkich przypadkach stwierdzić należy, że dane Rocznika okazują się niesprzeczne z informacjami czerpanymi z innych źródeł, a w jednym przypadku (biskupa Boguchwała) data śmierci znajduje wręcz wysoce prawdopodobne potwierdzenie. Generalnie uznać zatem można, że podawane przez Rocznik daty musiały zostać zaczerpnięte ze stojącego u jego podstawy katalogu.

Kształt katalogu można więc wyobrazić sobie następująco: stanowił listę kolejnych imion, przy których podane były daty — trudno orzec, czy w grę wchodziła tylko data śmierci (np. Peanus, obiit MCLII), czy też daty podwójne, ordynacji i śmierci (np. Peanus, ordinatus MCXLVI, obiit MCLIX). Najstarsze katalogi wrocławskie, które wydają się wzorcem dla poznańskiego, podawały daty podwójne (ordynacji i śmierci) ${ }^{34}$.

Śladem, aczkolwiek niezbyt pewnym, istnienia katalogu i jego funkcjonowania w świadomości kleru diecezjalnego mogło też być wykorzystywanie w najstarszych dokumentach biskupich rachuby poprzedników ${ }^{35}$. Biskup Benedykt w swym dokumencie pochodzącym zapewne z 1193 r. wspominał Radowana, który był piątym przed nim rządcą Kościoła poznańskiego ${ }^{36}$. Z kolei biskup Paweł w dokumencie z $1218 \mathrm{r}$. powoływał się aż na dwóch poprzedników, czwartego z rzędu Benedykta i drugiego Arnolda ${ }^{37}$. Obydwa dokumenty przeznaczone były dla poznańskich joannitów, więc być może praktyka liczenia biskupów pochodziła od odbiorcy. Tym bardziej wskazywałoby to jednak na opieranie się na jakiejś podstawie pisanej, pozwalającej na łatwe policzenie kolejnych pontyfikatów. Liczyć się jednak oczywiście trzeba także z możliwością dokonywania takich obliczeń z pamięci. Inną sprawą jest wiarogodność podawanej w dokumentach rachuby, która nie zgadza się z wiedzą o sukcesji biskupów przełomu XII i XIII w. ${ }^{38}$ Przypuszczać można, że w dokumentach tych stosowano odmienny od dzisiejszej praktyki sposób liczenia, tak że secundus ante nos oznacza tam po prostu poprzednika.

Trzymając się obserwacji, że Rocznik zawiera informacje o wszystkich biskupach, rozwiązać można kwestię identyfikacji biskupa Konrada, wymienionego w Roczniku lubińskim pod 1145 r. w charakterze konsekratora jednego z ołtarzy w klasztornym kościele ${ }^{39}$. Zachowana karta Rocznika obejmuje lata 1143-1176. Jako pierwszy na niej występuje biskup Boguchwał (zm. 1146). Zapis o jego

\footnotetext{
${ }^{33}$ G. Sappok, Die Anfänge, s. 87-88; J. Nowacki, Dzieje, t. 2, s. 49-51; J. Maciejewski, Episkopat, s. 252 n.; J. Dobosz, Monarchia, s. 320.

${ }^{34}$ Katalogi biskupów wrocławskich, s. 558-564; zob. O. Schmidt, Untersuchungen, s. 124-126; J. Szymański, Z zagadnień, s. 18.

${ }^{35}$ Zob. R. Żerelik, Praktyczne wykorzystanie katalogu dostojniczego w kancelarii Henryka z Wierzbna biskupa wrocławskiego, Sobótka, 48, 1993, s. 65-69. Nie ma związku ze znajomością katalogu fakt, że poznański biskup Jan (1286-1297) tytułował się jako Johannes secundus (KDWlkp., t. 2, nr 762). Wyróżniający liczebnik był tu potrzebny z tego względu, że bezpośrednim poprzednikiem Jana był jego imiennik.

${ }^{36}$ KDWlkp., t. 1, nr 29: dominus Rodovanus, quintus ante nos Poznaniensis episcopus.

37 Tamże, nr 104: tempore antecessoris nostri Benedicti, quarti ante nos episcopi Poznaniensis, a potem: beate memorie antecessor noster Arnoldus, secundus ante nos episcopus.

${ }^{38}$ Ustalenia dotychczasowej literatury (zob. G. Sappok, Die Anfänge, s. 91-99; J. Nowacki, Dzieje, t. 2, s. 52-55; J. Dobosz, Monarchia, s. 320) wymagają w tym fragmencie poprawek. Zmarły w 1211 r. Arnold musiał być bezpośrednim poprzednikiem wybranego w tym samym roku Pawła, a rzekomy biskup Filip nigdy nie istniał. Przed Arnoldem jako biskupów znamy Benedykta (poświadczony 1187-1193?) i Mrokotę (poświadczony 1195, zm. 1196). Ponieważ Arnold poświadczony jest dopiero od 1201 r., prawdopodobna wydaje się ewentualność, że nie był on bezpośrednim następcą Mrokoty.

${ }^{39}$ Komemorację biskupa Konrada mają też pod dniem 2 marca nekrologi ołbiński i lubiński (Nekrolog opactwa, s. 22; Księga bracka, s. 36, gdzie w komentarzu zestawienie dyskusji nad identyfikacją tej postaci).
} 
ordynacji musiał znajdować się na poprzedniej, zaginionej karcie Rocznika - a więc datowany mógł być najpóźniej na 1142 r. Jeżeli urzędowanie Boguchwała obejmowało przynajmniej lata 1142-1146, Konrad nie mógł być ordynariuszem poznańskim w 1145 r. Najprawdopodobniej chodzi tu o biskupa wrocławskiego, gdyż we Wrocławiu mamy w tym okresie lukę w znanej obsadzie tronu biskupiego, a inne diecezje polskie nie wchodzą w grę (bo znamy ich obsadę) ${ }^{40}$. Na podobnej zasadzie wskazać można, że ostatni z wymienionych na tej karcie biskupów (a więc Cherubin, uwzględniając wspomniane przestawienie osób) musiał umrzeć po $1176 \mathrm{r}$. Stwierdzenie to jest jednak jałowe poznawczo, wiemy bowiem skądinąd, jak pokazywałem wyżej, że żył on jeszcze w $1180 \mathrm{r}$.

Zachowane zapiski lubińskie pozwalają nam uchwycić tylko nieznaczny, dotyczący XII w., fragment katalogu. Jego dane przeniesiono do Rocznika, który znamy też tylko we fragmencie, obejmującym lata 1143-1176. Pierwotny katalog miał niewątpliwie szerszy zakres chronologiczny i zawierał imiona biskupów zarówno wcześniejszych (zapewne od restytucji biskupstwa w $1075 \mathrm{r}^{41}$ ), jak też i późniejszych. Zauważmy, że w zachowanym osobno drugim fragmencie Rocznika lubińskiego z lat 12471258 i 1263-1275 również znajdują się wiadomości o biskupach poznańskich (Boguchwale zm. 1252, Piotrze zm. 1253, Boguchwale zm. 1264, jego następcy Piotrze, który szybko zrezygnował, oraz Mikołaju konsekrowanym w 1266 r.). Znowu są one kompletne, obejmując wszystkich ordynariuszy z tego okresu. Te noty wniesione jednak zostały do Rocznika ręką jego głównego twórcy. Nie pochodzą więc z dopisków, a zatem nie ma podstaw by twierdzić, że zaczerpnięte zostały z katalogu. Ich podstawę stanowiły raczej zapiski prowadzone na bieżąco w opactwie lubińskim. Sam katalog, z którym ok. 1250 r. zapoznał się (przypuszczalnie w Poznaniu) lubiński zakonnik, był jednak najpewniej nadal cały czas kontynuowany, co leżało wszak w samej istocie tego typu zestawień. Trudno orzec, jak daleko mógł sięgać. W źródłach późnośredniowiecznych (z Długoszem na czele) nie widać już śladów znajomości najdawniejszych biskupów poznańskich. Długosz co prawda potrafił zaskakująco poprawnie podać niektóre imiona biskupów dwunastowiecznych ${ }^{42}$, ale popełniane przy okazji błędy i całkowita rozbieżność schematu chronologicznego wskazują, że na pewno nie mógł znać interesującego nas katalogu, czy to w wersji pierwotnej, czy choćby w postaci kompletnego Rocznika lubińskiego. Stary katalog zatem już wtedy nie istniał. Dobrym momentem jego zagłady wydaje się zniszczenie katedry w toku walk o Poznań w 1313 lub 1314 r. ${ }^{43}$, wcześniejszy bowiem pożar z 1267 r. nie wyrządził poważniejszych szkód ${ }^{44}$. Pozostała kopia w postaci zapisek annalistycznych Lubiniu, ale nie ma śladu, aby ten lokalny Rocznik był szerzej znany i wykorzystywany. W czasach nowożytnych rękopis, w którym znajdował się Rocznik, uległ zniszczeniu i został wykorzystany jako makulatura. Być może systematyczne poszukiwania w obfitej spuściźnie bibliotecznej opactwa lubińskiego pozwoliłyby odnaleźć i zidentyfikować kolejne odpryski tej niezwykle cennej dla dziejów biskupstwa poznańskiego tradycji ${ }^{45}$.

\footnotetext{
${ }^{40}$ Zob. T. Jurek, Zagadka, s. 5, 7; J. Dobosz, Monarchia, s. 323. Badacze biskupstwa poznańskiego (zob. przyp. 18) nie uznawali nigdy istnienia biskupa Konrada.

${ }^{41}$ Analogią służą znowu katalogi wrocławskie, rozpoczynające się od biskupa Hieronima ordynowanego przy restytucji biskupstwa w $1051 \mathrm{r}$.

${ }^{42}$ Katalog Długosza (Joannis Dlugossii Opera, t. I, s. 487-493) podaje następującą sekwencję biskupów: Boguchwał 1147-1150, Pean 1150-1151, Stefan 1151-1156, Radowan 1156-1162, Bernard 1162-1175, Świętosław 1175-1176, Gerward 1176-1177, Arnold 1177-1186, Mrokota 1186-1196, Filip 1196-1209, Paweł 1209-1242.

${ }^{43}$ Omawiający dzieje katedry romańskiej J. Nowacki, Dzieje, t. 1, s. 84-92, nie zauważa jej zniszczeń z 1313/1314 r., choć są one dobrze poświadczone (Joannis Dlugossii Annales, lib. IX, Warszawa 1978, s. 63-64; o pochodzeniu tej wiadomości: T. Jurek, Notes on the Natęcz, Family of Szamotuty. A Contribution to the Lords' Historiography in Medieval Poland, „Quaestiones Medii Aevi Novae", 12, 2007, s. 155-165).

${ }^{44}$ Roczniki wielkopolskie, s. 47 (Rocznik kapituły poznańskiej); zob. też tamże, s. 115 (Rocznik lubiński), 125 (Spominki poznańskie).

45 Nie ma śladu znajomości Rocznika w spisanym w połowie XVII w. dziele Antiquitates monasterii Lubinensis Bartłomieja Krzywińskiego (Poznań, AP, Benedyktyni Lubiń 236, dawniej C 30). Krzywiński znał dokumenty klasztorne, nekrolog, księgę bracką, ale zarazem przyznawał, że nie znalazł żadnych materiałów informujących o najstarszych opatach (s. 33: Qui primi monasterio huic ab anno fundationis eius circiter 1113 ad annum usque Christi 1238 successive praefuerint caenobiarchae, nichil expresse docent archivi nostri vetustates). Rocznik natomiast miał o nich sporo zapisów.
} 


\section{A Medieval Catalogue of the Bishops of Poznań Concealed within the Annals of Lubin}

Summary: A preserved fragment of the Annals from the Benedictine abbey in Lubin (southern Greater Poland), and written probably at the turn of the twelfth century, contains five added notes in handwriting from the middle of the thirteenth century. All the notes pertain to the bishops of Poznań arranged into a complete sequence from 1146-1172. Comparisons of information found in the Annals with other sources show that the notes about the bishops and the dates included therein are basically credible (with one exception when the author of the added information mistook the succession of the bishops). In all likelihood, they originate from a non-extant catalogue of the bishops apparently kept at Poznań cathedral, similarly as in the case of a majority of other Polish dioceses. This was a so-called simple catalogue, recording only the names of the consecutive ordinaries as well as the dates of their ordinations and death. The Lubin Annals notes enable us to recreate a fragment from the midtwelfth century but the catalogue as such was probably written from the time of the restoration of the Poznan diocese (ca. 1075) and existed in the thirteenth century (when data were copied from it in Lubin); its loss can be associated with a destruction of Poznan cathedral, confirmed in 1313-1314.

Nota o autorze: Tomas z Jurek, profesor zwyczajny, kierownik Zakładu Słownika Historyczno-Geograficznego Ziem Polskich w Średniowieczu w Instytucie Historii PAN, zajmuje się historią średniowiecza, zwłaszcza Śląska i Wielkopolski.

Author: To mas z Jurek, full professor, head of the Department of the Historical-geographical Dictionary of Polish Lands in the Middle Ages at the Institute of History of the Polish Academy of Sciences, specializes in mediaeval history, in particular of Silesia and Greater Poland.

Instytut Historii PAN, ul. Mielżyńskiego 27/29, 61-725 Poznań

e-mail: tnjurek@wp.pl

Źródła

\section{Bibliografia}

Katalogi biskupów krakowskich, wyd. J. Szymański, MPH s.n., t. 10, Warszawa 1974

Kodeks dyplomatyczny Wielkopolski, t. 1, [wyd. I. Zakrzewski], Poznań 1877

Roczniki wielkopolskie, wyd. B. Kürbis, MPH s.n., t. 6, Warszawa 1962

Opracowania

Dobosz J., Monarchia i możni wobec Kościoła w Polsce do początku XIII wieku, Poznań 2002

Gąsiorowski A., Najstarsze dokumenty poznańskiego domu joannitów, cz. 1, St. Źródł., 8, 1963, s. 83-95

Jurek T., Zagadka biskupa wroctawskiego Roberta, Sobótka, 45, 1990, s. 1-11

Karwowski S., Biskupi poznańscy z XII i początku XIII wieku, „Roczniki Towarzystwa Przyjaciół Nauk Poznańskiego", 37, 1911, s. 111-146

Maciejewski J., Episkopat polski doby dzielnicowej 1180-1320, Kraków-Bydgoszcz 2003

Nowacki J., Dzieje archidiecezji poznańskiej, t. 1-2, Poznań 1959-1964

Potkowski E., Fiktive Biographien in den Katalogen polnischer Bischöfe von Jan Dtugosz, w: Fälschungen im Mittelalter, Hannover 1988, t. I, s. 395-416

Repertorium polskich dokumentów doby piastowskiej, oprac. Z. Kozłowska-Budkowa, Kraków 1937 (wyd. 2: Kraków 2006)

Sappok G., Die Anfänge des Bistums Posen und die Reihe seiner Bischöfe von 968-1498, Leipzig 1937

Schmidt O., Untersuchungen zu den Breslauer Bischofskatalogen, Darstellungen und Quellen zur schlesischen Geschichte, t. 25, Breslau 1917

Szymański J., Z zagadnień średniowiecznej biografistyki. Katalogi dostojnicze. Studium źródtoznawcze, Warszawa 1969

Żerelik R., Praktyczne wykorzystanie katalogu dostojniczego w kancelarii Henryka z Wierzbna biskupa wroctawskiego, Sobótka, 48, 1993, s. 65-69 